\title{
Sobre poesia e pintura em Herberto Helder
}

Geovanna Marcela da Silva Guimarães

UFPA

\begin{abstract}
Resumo
Analisar o barroco em Herberto Helder é tentar mostrar como os aspectos formais e estéticos do barroco permanecem na modernidade e de que maneira eles são processados na obra poética herbertiana. Sendo assim, o objetivo deste trabalho é propor uma análise crítica dos "traços barrocos" presentes em Herberto Helder, enfatizando que esta análise crítica é também uma nova proposta de leitura de sua obra, amplamente debatida e estudada. Para isso nos valeremos da equivalência, desde sempre considerada, entre poesia e pintura que é possível ser vista na obra do poeta português, mais especificamente, nos livros Servidóes (2013), A morte sem mestre (2014) e nos contos "Teoria das cores" e "Escadas e Metafísica" do livro Os passos em volta (1963).

Palavras-chave: Herberto Helder; Poesia; Pintura.
\end{abstract}

\begin{abstract}
Analysing the baroque elements in Herberto Helder's works is trying to show how the formal and aesthetic aspects of the baroque style remain in the modernity and how they are processed in the herbetian poetic. This work aims to do a critical analysis of "baroque remainings" presented in Herberto Helder's works, knowing this is a new way in reading his texts. We use the bridge between poetry and painting as methodology, as seen in the books Servidóes (2013), A morte sem mestre (2014) and in the tales "Teoria das Cores" and "Escadas e Metafísica”, parts of the book Os passos em volta (2013).
\end{abstract}

Keywords: Herberto Helder; Poetry; Painting. 
1 KRYSINSKI, Wladimir. "Os barroquismos da modernidade", 2008, p. 164-185.

2 Ibidem, p. 165.

3 Ibidem, p. 166.

4 Ibidem, p. 165.
Wladimir Krysinski ${ }^{1}$ considera que as relaçóes entre o barroco e a modernidade devem ser repensadas e ressituadas em um contexto discursivo e crítico pertinentes, pois para ele, "os barroquismos da modernidade [estão assentados nas noçóes] de reciclagem do barroco [e] reescrita da modernidade, [bem como] nas relaçóes entre vanguarda e o novo." ${ }^{2}$ Entretanto, tais noçôes, como quaisquer outras, apresentam pontos suscetíveis de questionamento, sendo um deles destacado pelo próprio autor, referente ao debate sobre a validade e qualidade do termo "reciclagem", que é usado para nomear a presença de técnicas artísticas barrocas na modernidade como sendo a encenação do novo pelas artes de vanguarda. De acordo com o autor, o termo "reciclagem" é possuidor de uma coloração tecnológica, ecológica e intelectual que se utiliza de "procedimentos técnicos que determinam uma relação estritamente material com os objetos literários reconhecidos como entidades manipuláveis e transformáveis. Assim sendo, a reciclagem retira alguma coisa da dimensão espiritual e criadora da literatura."3 Dessa maneira, os pontos de questionamento das concepçôes de barroco, modernidade, reciclagem e vanguarda, na verdade, mostram que a "permeabilidade e a falta de determinação facilitam e complicam a análise de obras que surgiram e que surgem nos horizontes históricos e geográficos da modernidade", ${ }_{4}^{4}$ sendo que a principal complicação dessa permeabilidade e indeterminação é o uso indiscriminado dos referidos termos sem uma proposta real de análise dos objetos escolhidos para estudo, principalmente no que diz respeito ao estudo do barroco.

Para Krysinski, a grande dificuldade dos estudos sobre o barroco na modernidade é o fato de que os estudos das obras modernas consideradas barrocas são apenas de caráter descritivo e não analítico. Ou seja, obras modernas são definidas, classificadas como barrocas sem que suas ditas características barrocas sejam identificadas tanto em suas funções quanto em seus aspectos formais e estéticos, o que faz com que elas, simultaneamente, possuam características ora antigas ora modernas. Com isso vemos que essas definiçôes indiscriminadas acabam provocando o uso do termo "barroco" como um adjetivo para classificar obras modernas consideradas complexas, aquelas que apresentam estrutura e linguagem difíceis de serem compreendidas ou analisadas, e uma "confusão" histórica, uma vez que ao denominar uma obra como barroca acaba-se por remetê-la a um tempo histórico totalmente distinto do seu tempo de produção e escrita.

A partir disso, somos levados a compreender que o que se encontra presente na modernidade não é propriamente o barroco, mas sim seus traços, aspectos, sobretudo, seus efeitos e funçôes. Nesse caso, para o autor, a mobilidade escrita dos textos modernos que encenam a possibilidade dos diversos barroquismos possui dois lados: um positivo e um negativo, sendo 
o primeiro o da criação e o segundo o da destruição, que se condicionam mutuamente e reciprocamente, subvertendo um ao outro. Para o autor, um exemplo dessa mobilidade incessante entre criação e destruição pode ser visto em Galáxias (1984), de Haroldo de Campos, que é considerado por ele como "um texto moderno que se nutre constantemente da dobra e da proliferação barrocas" 5 cuja escrita combina estruturalmente e linguisticamente prosa e poesia, além de diversas literaturas e culturas. $\mathrm{O}$ poema haroldiano não possui nenhuma paginação ou qualquer outro tipo de sinalização que seja possível situar o leitor no ato de leitura e fruição da obra, pois a principal e grande premissa do poema é a encenação da intercambialidade da criação poética e da escrita como viagem sem fim, onde o (re)começar incessante sempre será possível. A análise da obra haroldiana é a exemplificação das afirmaçôes de Krysinski sobre os barroquismos na modernidade. Além disso, é a proposta das diversas possibilidades de se estudar os "traços barrocos" das obras modernas, porém por meio de um viés crítico e reflexivo que pensa a funcionalidade e os sentidos dos aspectos formais e estéticos desses traços.

Sendo assim, seguindo o que é proposto pelo autor, veremos que um exemplo de obra moderna considerada barroca, porém sem a avaliação de suas características barrocas, é a obra do poeta português Herberto Helder, vista deste modo por muitos dos seus principais críticos, tais como Maria Lúcia Dal Farra, Jorge Henrique Bastos, Maria dos Prazeres Gomes e Eunice Ribeiro. Entretanto, o que notamos na maioria das afirmaçôes é que a "consistência" desse barroco nem sempre é analisada de forma que sejam explicadas as funçôes, efeitos e identidades dos muitos "traços barrocos" presentes na obra de Herberto Helder. Contudo, com a leitura de Krysinski, vemos que os "traços barrocos" da obra herbertiana são marcados pela "insistência do subjetivo e do auto-reflexivo [uma vez que seus] poemas não são descontínuos [...] mas são suficientemente trabalhados pelo gesto dialético de paixôes absolutas, o amor, o ódio, a desgraça, a alienação, a escrita, a ruptura.”

Além disso, é necessário ter em mente que os barroquismos presentes em Herberto Helder são exatamente aqueles comumente definidos como os do exagero ou do excesso, que irão se manter presentes por suas "qualidades" de obras abruptas e incessantes onde os "dados de invenção" serão extremamente importantes. Nesse sentido, analisar os "traços barrocos" de Herberto Helder nos possibilita ler sua obra poética por "diferentes vias interpretativas", ${ }^{8}$ tal como afirma Cláudio Daniel sobre as obras modernas possuidoras de características barrocas. Sendo assim, o objetivo deste trabalho é tentar mostrar como os aspectos formais e estéticos do barroco permaneceram na modernidade e de que maneira eles são processados na obra poética de Herberto Helder. Com isso propomos uma análise crítica
5 Ibidem, p. 183.

6 Ibidem, p. 178.

7 Ibidem, p. 184.

8 DANIEL, Cláudio. "Releituras do barroco na modernidade". Psicanálise e Barroco em revista, v. 6, n. 1, julho 2008, p. 86-92. 
9 HELDER, Herberto. "Servidóes”. In: Poemas Completos. Porto: Porto Editora, 2014, p. 625.

10 JÚDICE, Nuno. "As fronteiras do poético na poesia de Herberto Helder". Diacritica: Revista do Centro de Estudos Humanisticos, $\mathrm{n}$. 23/3, 2009a, p. 147.

11 JÚDICE, Nuno. "Um conceito de poética". ABRIL - Revista do Núcleo de Estudos de Literatura Portuguesa e Africana da UFF, v. 2, n 3, novembro, 2009b.

12 Antônio Ramos Rosa, apud. JÚDICE, Nuno. "Um conceito de poética”, 2009b, p. 157.

13 Antônio Ramos Rosa, apud. JÚDICE, Nuno. "Um conceito de poética”, 2009b, p. 157.

14 JÚDICE, 2009b, p. 158.

15 Ibidem, p. 158.

16 Ibidem, p. 158.

17 DELACROIX, Eugène. "Diário $(1822,1853,1854)$ ”, 2005, pp. 93-101.

18 DU BOS, Jean-Baptiste. "Reflexôes críticas sobre a poesia e a pintura”, 2005, pp. 60-73. dos traços barrocos presentes na obra do poeta português, enfatizando que esta análise crítica é também uma nova proposta de leitura de sua obra, amplamente debatida e estudada. Nesse caso, assumiremos o risco de achar nossa "própria cegueira, a vista de uma paisagem transfigurada".

Primeiramente, é importante destacar que analisar os "traços barrocos" da obra poética de Herberto Helder a partir da relação entre poesia e pintura é levar em conta que dentro da obra do poeta português não há uma delimitação estrita entre prosa e poesia, uma vez que, segundo Nuno Júdice,

O que distingue a escrita de Herberto Helder é precisamente
esta (sobre)determinação do poético que se encontra tanto nos
poemas "canónicos» (em verso) como na sua prosa, embora essa
prosa se distinga daquilo a que se chama "prosa poética» por
uma incisão narrativa que não se afasta muito de uma ficciona-
lização subjacente ao próprio texto em verso que, quando não
atinge esse patamar, se fixa num fundo cénico, feito de elemen-
tos substantivos, designando cenário e personagens. ${ }^{10}$

Com a leitura de outro texto do autor, ${ }^{11}$ vemos que essa "(sobre)determinação" entre prosa e poesia é o que proporciona o caráter renovável dos textos herbertianos, que sempre, a cada nova leitura, irão mostrar algo novo, em razão de que em sua existência - aquilo "que pressupóe coerência, individualidade, unicidade, o que é por si mesmo"12 - e densidade - a "estrutura complexa e una, o dado inicial de percepção do poema"13 - possuem "um mecanismo produtor de sentido(s) que é o posto em funcionamento, e adquire uma característica renovável". ${ }^{14}$ Sendo que, neste artigo, a "característica renovável" da poesia herbertiana que aqui destacamos é, justamente, a relação entre poesia e pintura como forma de demarcar e analisar a presença de "traços barrocos" na poesia contemporânea do poeta português.

A eleição de uma "característica renovável" dentro da obra poética de Herberto Helder permite que seus textos sejam incluídos "dentro do que se chamaria uma recriação perpétua (perpetuum mobile)", ${ }^{15}$ que, segundo o autor, recuperaria "o projeto barroco que nasce da glosa e da variação, repetidos até a exaustão". ${ }^{16}$ Com isso, vemos que a obra poética herbertiana é, antes de mais nada, uma obra poética contemporânea que se vale de características barrocas como forma de construção e produção de sentido, no que seria a proposta de uma nova escrita poética.

Porém, é preciso esclarecer que a relação poesia e pintura aqui defendida não é aquela tradicional, tal como é concebida por críticos de arte e artistas, tais como Eugène Delacroix ${ }^{17}$ e Du Bos, ${ }^{18}$ onde é possível ver no texto lite- 
rário a encenação de um quadro tal como o conhecemos com suas formas e cores, mas uma que se encontra intimamente ligada a noção de construção de imagens poéticas pelo imaginário, tal como defendido por Rosa Maria Martelo. ${ }^{19}$ Imagens estas criadas pelo imaginário do poeta e apreendidas pelo imaginário do leitor, que serão a demonstração da capacidade de produzir e interpretar imagens de ambos. O que nos faz entender que a pintura no texto literário é encenada por meio da escrita, sendo solicitado ao leitor o "olhar" do imaginário para que a imagem pictórica possa ser "vista" em suas cores e formas. Nesse sentido, a pintura é dada a ser "lida" e "imaginada" no texto literário. Um exemplo disso é o seguinte trecho do conto herbertiano "Escadas e Metafísica", onde temos a encenação da "relação dinâmica entre os objetos, recorrendo a interpenetração [deles com] as palavras" ${ }^{20}$ a partir da observação de uma paisagem pela janela de um quarto alugado:

\footnotetext{
Aluguei então um quarto no sexto andar de um prédio nas traseiras da Sé. Conhecem esses edifícios velhos, com patamares e cancelas insólitas, súbitas derivaçôes de corredores e escadas de três degraus partindo da escada principal para uma porta enigmática, pintada de castanho-escuro e com uma aldraba monstruosa? [...]. Aluguei o quarto. Deitava para o rio onde eu via mastros e cascos sujos de barcos. Mesmo em frente erguia-se a torre da igreja, e a confusão das construções apensas ao corpo principal do edifício. Não lhes dei muita importância. Olhei melhor o rio e a outra margem, os exíguos quintais à roda, um miradoiro junto a entrada da Sé com gente sentada nos verdes bancos. Os eléctricos atroavam a calçada abaixo. Das janelas pendiam roupa encardida. Avistam-se crianças bonitas e tristes através das vidraças. Alguém cantava, e o rio estava defronte, claro e lento, tão antigo quando me punha a olhar muito para as águas. Voltei as costas à janela. A torre caía sobre mim. Ou observa-me cegamente. ${ }^{21}$
}

A paisagem para Ida Ferreira Alves é um "dado construído, envolvendo percepção, concepção e ação" 22 sendo o "resultado de uma construção perceptiva e cultural, constituindo uma estrutura de sentidos, uma formulação subjetiva configuradora de mundos a viver." ${ }^{23}$ Segundo a autora, nos respectivos textos, a "construção perceptiva e cultural" da paisagem está alicerçada em parâmetros de subjetividade, identidade, alteridade, perspectiva, olhar, conhecimento e experiência de mundo. $\mathrm{O}$ que demonstra que a existência da paisagem é tal como a de um "jogo de textualidades" ${ }^{24}$ onde é solicitado ao leitor o "ver" e o "pensar", evidenciando que o "ato de escrita poética encontra seu duplo no ato de leitura" ${ }^{25}$

Sendo assim, para a autora, falar em paisagem no texto poético é "discutir a percepção [da] paisagem como percepção sobre habitar o mundo e habitar a escrita." ${ }^{26}$ No caso do conto de Herberto Helder, a paisagem
19 MARTELO, Rosa Maria. "De imagem em imagem”. ABRIL Revista do Núcleo de Estudos de Literatura Portuguesa e Africana da UFF, v. 5, n. 9, novembro de 2012, p. 15-26.

20 SOARES, Maria Leonor Barbosa. "Formas e sentidos do barroco na arte contemporânea". Actas do II Congresso Internacional do Barroco, 2003, p. 554.

21 HELDER, Herberto. "Escadas e Metafísica”, 2013, p. 67-68.

22 ALVES, Ida. "Paisagem, aceleração e poesia por uma geografia das emoçóes". Revista de Letras, n.34, v.1, p. 29.

23 Ibidem, p. 29.

24 Ídem. "Em torno da paisagem: literatura e geografia em diálogo interdisciplinar”. Revista da Anpoll, n.35, Florianópolis, p. 200.

25 Ibidem, p. 192.

26 Ibidem, p. 192. 
27 Ibidem, p. 193.

28 Ibidem, p. 193.

29 HELDER, Herberto. Os passos em volta, 2013, p. 67-68.

30 JÚDICE, Nuno. "Um conceito de poética”. Abril. Revista do Núcleo de Estudos de Literatura Portuguesa e Africana da UFF, v.2, n.3, 2009b, p. 147.

31 SOARES, Maria Leonor Barbosa. "Formas e sentidos do barroco na arte contemporânea”. Actas do II Congresso Internacional do Barroco, 2003, p. 553.

32 Ibidem, p. 555.

33 ALVES, Ida. "Paisagem e poesia: uma certa maneira de ver e escrever". Anais do $X I$ Congresso Internacional da ABRALIC Tessituras, Interaçóes, Convergências, 2008, s/p.

34 HELDER, Herberto. "Os comboios que vão para Antuérpia”, 2013, p. 47

35 HELDER, Herberto. "Vida e obra de um poeta", 2013, p. 147. observada pela janela, é "um conjunto de imagens que o olhar reúne e ao qual dá significado a partir de uma determinada perspectiva." ${ }^{27}$ Além disso, a janela do quarto alugado seria o "enquadramento para a ação de ver [...] a janela cotidiana [com] os olhos por meio dos quais [olhamos] o mundo exterior." ${ }^{28}$ No referido trecho, a relação entre poesia e pintura, a partir da presença da paisagem no texto literário, ocorre no plano textual e da escrita, que só é alcançado ao nível da leitura e da imaginação: "Conhecem esses edifícios velhos, com patamares e cancelas insólitas, súbitas derivaçôes de corredores e escadas de três degraus partindo da escada principal para uma porta enigmática, pintada de castanho-escuro e com uma aldraba monstruosa?”29 Àqueles que conhecem tais edifícios não haverá tantas dificuldades para imaginar, mas àqueles que não os conhecem será solicitado um maior esforço de imaginação. Em Herberto Helder, poesia e pintura é o apelo ao imaginário e a capacidade de produzir e interpretar imagens.

O que nos revelará que até mesmo o imaginário é possuidor de uma capacidade lógica, uma articulação racional, que "não necessariamente coincide com a lógica do pensamento racional", ${ }^{30}$ capaz de (des)organizar as imagens criadas pelo poeta perante os olhos do leitor. Tal pensamento dialogará com o de Maria Leonor Barbosa Soares sobre as relações existentes entre a arte barroca e a arte contemporânea. Para Soares, uma das relaçóes entre arte barroca e arte contemporânea é o uso da imagem como meio de comunicação privilegiado, "que inclui um apelo multisensorial [que] provoca o maior grau de envolvimento possível do observador", ${ }^{31}$ movido pela "tensão dinâmica e a apreensão do movimento como experiências vitais" ${ }^{32}$

Desta maneira, os estudos de Alves mostram-se bastante pertinentes para a discussão desenvolvida neste texto, uma vez que consideramos a relação poesia e pintura não nos moldes tradicionais, como já falamos antes, mas sim como a possibilidade do "discurso poético [desde sempre ser um] discurso predominantemente imagético." ${ }^{33}$ Sendo assim, com a leitura dos textos de Alves e a análise do texto herbertiano, vemos que na poética de Herberto Helder há a mistura do que a autora chama de território cultural e território simbólico, no que seria a encenação de um configurar e desfigurar da realidade, nas suas experiências de subjetividade e identidade. É o que podemos ver nos contos "Os comboios que vão para Antuérpia", "Descobrimento" e "Vida e obra de um poeta", onde temos, por meio da paisagem, o vislumbrar de uma "Antuérpia [de] inspiração difusa, confusa" ${ }^{34}$ e da vontade de morrer em uma retrete em Paris somente com o pressentimento do segredo das coisas: "Morrerei como se fosse numa retrete em Paris - só, com a minha visão, o pressentido segredo das coisas". ${ }^{35}$ Nestes referidos contos podemos ver também o que Alves considera como os diferentes tipos de movimento que relacionam subjetividade e paisagem: 
1 - no âmbito físico-espacial (enlaces do corpo com o espaço exterior, com a natureza, corpo em movimento nos meios de transporte, com alteração de perspectivas e percepçóes da realidade); 2 - no âmbito semântico e imagético (referências a, movimentos, deslocamentos, trânsitos, transferências, viagem, nomadismo, aceleração e ideias correlatas) e 3 - no âmbito da textualidade (práticas de movimento da própria escrita - a citação, a colagem, referências cruzadas, processos intertextuais, intersemióticos e interculturais). ${ }^{36}$

As duas últimas é que se farão presentes na poética herbertiana, uma vez que o livro Os passos em volta é o relato, em discurso poético, de experiências de subjetividades e identidades, mostrando como cada lugar, espaço, situação é vivenciado e experenciado por um indivíduo. Porém, para compreendermos melhor como isso ocorre será necessário discutirmos o papel da imagem e do olhar na poética herbertiana, a partir da noção de que eles são uma nova dimensão da relação poesia e pintura, como forma de analisar os "traços barrocos" em Herberto Helder.

A análise dos aspectos formais e estéticos do barroco em Herberto Helder nos permite também discutir as transformaçôes do papel da crítica na poesia contemporânea, uma vez que a poesia herbertiana, em sua escrita barroquizante, ao valer-se dos diversos barroquismos, mostra que sua base de invenção e criação é a transmutação das coisas do mundo em imagens altamente poéticas, sendo que esta transmutação não é possuidora de um caráter estático, mas sim de um caráter movente, cuja principal qualidade é a encenação da velocidade incessante do desdobramento das coisas do mundo, onde o leitor é instigado "a se embrenhar em um universo desnorteante de palavras que estabelecem conexóes intrigantes e inesperadas." 37

Contudo, em se tratando da modernização do barroco, vemos que o caráter movente da poesia herbertiana atualiza a própria noção de movimento do barroco proposta por Heinrich Wölfflin: ${ }^{38}$ o movimento da arte barroca era um estado opositivo ao caráter isolado e estático da arte renascentista, sendo que sua principal função era mostrar o todo orgânico de um determinado corpo. No que se refere aos traços barrocos em Herberto Helder, veremos como a organicidade de um corpo é encenada não apenas pelo movimento veloz da linguagem poética, mas também pela equivalência, desde sempre considerada, entre poesia e pintura. É o que podemos ver no seguinte fragmento de Servidóes, onde movimento, organicidade, pintura e poesia
36 ALVES, Ida Ferreira. "Paisagem, aceleração e poesia por uma geografia das emoçóes". Revista de Letras, n.34, v.1, jan./jun. de 2015 , p. 30 .

37 PITERI, Sônia Helena de Oliveira Raymundo. "Palavras em desdobramento na poesia de Herberto Helder". Forma breve, n. 7, 2010, p. 395 .

38 Cf. WÖLFFLIN, Heinrich. Renascença e Barroco, 2012. 
39 HELDER, Herberto. "Servidóes”, 2014, p.621-622. (Grifo nosso)

40 WÖLFFLIN, Heinrich. Renascença e Barroco, 2012, p. 54.

41 HELDER, Herberto. "Servidôes”, 2014, p.621-622.

42 Ibidem, p. 622.

43 Ibidem, p. 661. agem de forma ativa para que o leitor consiga "ver", tal como num quadro, o esquartejamento de um porco:

Trouxeram uma vez um porco selvagem caçado nas serras e atiraram-no para cima da mesa da cozinha, uma longa mesa coberta de zinco. Abriram-no de alto a baixo com enormes facalhóes e cutelos, o sangue corria por todos os lados, meteram as mãos e os antebraços na massa vermelha, e eles reapareceram depois como calçados de luvas sangrentas, vivas, deitaram em baldes as vísceras que fumegavam: os pulmóes, o fígado, os intestinos. De tudo aquilo subia um perfume agudo, embriagador, doloroso. À noite tive febre. Havia qualquer coisa pérfida e perversa neste mundo das frutas muito fortes, dos animais esquartejados, dos cheiros, este mundo espesso e quente, um mundo de imagens orgânicas. ${ }^{39}$

Com Wölfflin, veremos que a organicidade, a grande geradora de movimento que é representada no seguinte fragmento, é o "acontecimento, [a] expressão de [um] determinado [...] corpo", ${ }^{40}$ que, no caso, é o do porco. Além disso, essa organicidade com suas carnes e sangue, não é feita de forma impensada, irracional, irresponsável, ela é feita de tal modo que o leitor seja capaz, por meio da imaginação e da leitura (visão), de olhar e imaginar a cena do esquartejamento e de sentir os seus efeitos, por meio de "um perfume agudo, embriagador, doloroso", uma vez que todos os textos herbertianos são "linhas sem tropeço, de osso, nervo, sangue, sopro". ${ }^{41}$ No referido fragmento vemos também que o mundo de imagens poéticas de Herberto Helder é extremamente orgânico e tingido pela cor viva e quente do vermelho, onde todos os seres animados e inanimados ganham vida para mostrar que o mundo é uma totalidade visceral e carnal: "As bananeiras gemiam de noite: a sua carne rasgava-se por uma força que vinha de dentro, e das feridas brotavam os rebentos cachos, frutas de ouro." ${ }^{42}$

O orgânico será uma imagem poética recorrente em Herberto Helder, principalmente no que refere à relação entre poesia e pintura, pois já que o mundo é orgânico, a poesia e, consequentemente, o poema, também o serão: "nada pode ser mais complexo que um poema, / organismo superlativo absoluto vivo.” ${ }^{43}$ Dessa maneira, mundo e poesia serão regidos pelo incessante jogo entre vida e morte; nascer e morrer, que representam a mudança, renovação e transformação fundamentais de todos os seres vivos ou não. É o que podemos ver nos versos "e eu que sopro e envolvo teu corpo tremulamente intacto com meu corpo de bode coroado" que dialoga com o poema camoniano "Mudam-se os tempos, mudam-se as vontades": 
e eu que sopro e envolvo teu corpo tremulamente intacto com meu corpo de bode coroado

fedendo a testosterona e sangue,

[...]

e de minha bruteza te encurvas tanto que te sussurro um poema de louvação e embalo,

tão soluto e agudo e soberano,

algures, quando,

a água quebre e os verbos soberbos cantem,

e tudo se desfaça,

e refaça,

não como soía,

mas com um assombro novo:

faz-se-me tarde para o poema das frutas que de macias se fedem e fundem nas gengivas,

e no ímpeto da luz rasgada em baixo,

cômo-te antes que morra:

e eu sei quanto depressa morro ${ }^{44}$

Mudam-se os tempos, mudam-se as vontades,

Muda-se o ser, muda-se a confiança;

Todo o mundo é composto de mudança,

Tomando sempre novas qualidades.

Continuamente vemos novidades,

Diferentes em tudo da esperança;

Do mal ficam as mágoas na lembrança,

E do bem, se algum houve, as saudades.

O tempo cobre o chão de verde manto,

Que já coberto foi de neve fria,

E enfim converte em choro o doce canto.

E, afora este mudar-se cada dia,

Outra mudança faz de mor espanto:

Que não se muda já como soía. ${ }^{45}$
45 CAMÔES, Luís de. "Mudamse os tempos, mudam-se as vontades", 1977, p. 45. (Grifo nosso)

A comparação entre os dois poemas mostra-nos a reação do sujeito perante o fenômeno natural da mudança, sendo que a reação dos eu-líricos dos respectivos poemas é a mesma: ambos ficam assombrados ante a mudança das coisas do mundo, porém a natureza de tal assombro é que se distinguirá de um para outro: o assombro do eu-lírico camoniano é, podemos assim dizer, de um caráter melancólico por ver que as coisas já não mudam como de costume. Não há mais a mudança habitual e natural das coisas, enquanto que o assombro do eu-lírico do poema herbertiano é de um caráter fora do comum, uma vez que ele anseia a mudança, mas não a mudança habitual e natural, mas sim a mudança nova, aquela produtora de um "assombro novo", sempre fazendo-se e refazendo-se. Ou seja, a mudança para Herberto Helder é bem-vinda, porém ela deve trazer algo novo, que nunca antes foi visto, contudo veremos que este "assombro novo", ambicionado 
46 WÖLFFLIN, Heinrich. Renascença e Barroco, 2012, p. 47-48.

47 HELDER, Herberto. "A morte sem mestre”, 2014, p. 751. por Herberto Helder é, na verdade, o acontecimento, o devir, que, segundo Wölfflin serão as verdadeiras evocaçôes das artes barrocas:

O Barroco [...] quer dominar-nos com o poder da emoção de modo imediato e avassalador. $\mathrm{O}$ que traz não é uma animação regular, mas excitação, êxtase, ebriedade. Visa produzir a impressáo do momento [...] O Barroco exerce momentaneamente um efeito poderoso, mas em breve nos abandona, deixando-nos uma espécie de náusea.

Ele não evoca a plenitude do ser, mas o devir, o acontecer; não a satisfação, mas a insatisfação e a instabilidade. Não nos sentimos redimidos, mas arrastados para a tensão de um estado apaixonado. ${ }^{46}$

Um exemplo do "poder da emoção de modo imediato e avassalador" que em "breve nos abandona" pode ser visto no seguinte poema herbertiano:

folhas soltas, cadernos, livros, montōes inexplicáveis, e cada vez que lhes toco fica tudo mais caótico e não descubro nada, às vezes procuro apenas uma palavra que algures na desordem estava certa,

nos âmagos e umbigos da alma:

brilhava,

uma vez encontrei um relâmpago, e quase morri de assombro, quase via alguma coisa nos jardins de outro mundo, quase via fogo que nascia,

quase irrompeu um poema quase sem uma palavra errada, quase me tocaram, quase nasci ali mesmo nesse ápice da terra inteira, quase que a mão esquerda se moveu dentro da desordem, quase tinha pegado o fogo mas já estava fora, quase todo eu era matéria-prima, mas de repente não, de repente as coisas colocadas regressavam e entre elas, dentro, sentado, eu apenas escrevia isso, caótico como era antes: livros, folhas soltas, cadernos, etc., este pequeno poema que deixava tudo revôlto como dantes era, e eu não tocava em nada e nada me tocara, e nada se tocara entre si, e eu morria aos poucos como era costume na época. ${ }^{47}$

Neste poema vemos que todas as possíveis realizaçóes nunca de fato se concretizam. O "quase" é a suspensão da provável ação que na maioria das vezes poderia satisfazer o poeta que "quase irrompeu um poema quase sem uma palavra errada", mas que, na verdade, nunca o conseguiu fazer e que, possivelmente nunca conseguirá; nem o poema e nem a pureza da linguagem de fato acontecerão. Para acalmar, essa "espécie de náusea" e poder ser 
arrastado para "a tensão de um estado apaixonado", Herberto Helder dirá que o grande prestígio da poesia é "apanhar as coisas na sua fortuita distração" ${ }^{48}$ não havendo, assim, o intuito da representação fiel do real, mas sim o de representar o que é impossível de ser representado, aquilo que está fora do olhar comum, ou seja, ver o que está na exterioridade da linguagem e, assim, tornar possível o fazer poético.

A representação do irrepresentável na poesia só poderá ser possível na escrita com a criação de imagens poéticas, possuidoras da capacidade de "converter um estado de coisas noutro estado de coisas, deslexicalizando os nomes, desviando-os do seu uso comum." ${ }^{49}$ Para compreender isso melhor, tomemos como a base análise de Rosa Maria Martelo dos pressupostos de Ana Hatherly e Gastão Cruz acerca da imagem na poesia portuguesa, que considera a produçấo da imagem como a relação entre a percepção visual e a espacialidade gráfica, sendo que, nesse caso, as imagens dentro da poesia não serão exteriores à linguagem, na verdade, elas serão a própria exterioridade da linguagem.

Ao dar prosseguimento à leitura do texto de Martelo, que cita Antoine Janvier, vemos que a equivalência entre pintura e poesia nos textos herbertianos é um "faire voir" voltado para o imaginário, onde as imagens poéticas criadas pelo poeta português são voltadas para a encenação da transmutação das coisas do mundo como forma de dar sentido e vazão à organicidade de todos os seres. Outro aspecto interessante que podemos observar na discussão sobre imagem e que também é abordado por Martelo, que é proveniente da leitura da autora da obra Au fond des images (2003) de Jean-Luc Nancy, é a noção de "fundo de texto": "Jean-Luc Nancy é um dos autores que defendem essa perspectiva, mas o filósofo complementa-a considerando que [...] ao fundo do texto há sempre imagem." ${ }^{50} \mathrm{O}$ que nos faz ver que visão e olhar são coisas totalmente distintas uma da outra: o olhar está ligado ao imaginário, ao "faire voir", enquanto que a visão liga-se à apreensão do senso comum.

No poema, a imagem é vista e ouvida através das palavras: "O materialismo linguístico [exerce-se] entre som e imagem, entre iconicidade e sentido, 'pensamento visual', exploração desse fundo de forma e de visão que existe no texto, como pretende Nancy." ${ }^{51}$ Desta maneira, podemos considerar este "fundo do texto" como um dos configuradores da relação entre poesia e pintura. É o que podemos ver no conto herbertiano "Teoria das cores", originalmente publicado em 1962, onde temos a encenação, ao "fundo do texto", da poesia, pintura, movimento e metamorfose, demonstrando que nada é estático ou impassível:
48 HELDER, Herberto. "Servidóes", 2014, p. 623.

49 MARTELO, Rosa Maria. "De imagem em imagem". Abril. Revista do Núcleo de Estudos de Literatura Portuguesa e Africana da $U F F$, v.5, n.9, novembro de 2012, p. 18.

50 Ibidem, p. 19.

51 Ibidem, p. 24. 
52 HELDER, Herberto. "Teoria das cores", 2013, p. 21-22.

53 LINS, Vera. "Fragmentos sobre poesia e pintura”. Alea: Estudos Neolatinos, v.3, n.2, p. 24.

54 Ibidem, p. 25.
Era uma vez um pintor que tinha um aquário com um peixe vermelho. Vivia o peixe tranquilamente acompanhado pela sua cor vermelha até que principiou a tornar-se negro a partir de dentro, um nó preto atrás da cor encarnada. $\mathrm{O}$ nó desenvolvia-se alastrando e tomando conta de todo o peixe. Por fora do aquário o pintor assistia surpreendido à chegada do novo peixe. O problema do artista era que, obrigado a interromper o quadro onde estava a chegar o vermelho do peixe, não sabia o que fazer da cor preta que ele agora lhe ensinava. Os elementos do problema constituíam-se na observaçáo dos factos e punham-se por esta ordem: peixe, vermelho, pintor - sendo o vermelho o nexo entre o peixe e o quadro, através do pintor. $\mathrm{O}$ preto formava a insídia do real e abria um abismo na primitiva fidelidade do pintor.

Ao meditar sobre as razóes da mudança exactamente quando assentava na sua fidelidade, o pintor supôs que o peixe, efectuando um número de mágica, mostrava que existia apenas uma lei abrangendo tanto o mundo das coisas como o da imaginação. Era a lei da metamorfose.

Compreendida esta espécie de fidelidade, o artista pintou um peixe amarelo. ${ }^{52}$

Vera Lins nos apresenta algumas consideraçóes acerca do trabalho artístico desenvolvido tanto na pintura quanto na poesia, assim como seus respectivos papéis na modernidade, sendo que o que aproxima ambas as artes é o desejo de captar "a textura imaginária do real". ${ }^{53}$ Tal desejo de captação está ligado ao questionamento de como representar o irrepresentável, o absoluto, pois é isso que marca a arte moderna: "a afirmação da categoria do irrepresentável e a tentativa de apresentá-lo pela imagem, no sublime, no grotesco ou na arte abstrata. ${ }^{54} \mathrm{O}$ questionamento do real pode ser visto no referido conto de Herberto Helder citado acima: como representar o irrepresentável, que no caso é a metamorfose, sendo que o pintor até então nem sabia da sua existência e desejava a fidelidade da representaçáo? A resposta de Herberto Helder é simplesmente pintar o peixe segundo sua vontade, abrindo mão, totalmente, de uma (im)possível representação do real.

Compreende-se que a descoberta do pintor/poeta, por meio da observação da metamorfose do peixe, ocorre a partir do entendimento de que a arte é a expectativa de criação de um mundo possível, que só é produzido pelo conhecimento de que a metamorfose do mundo, costumeira ou não, retomando o diálogo entre Camóes e Herberto Helder, é um acontecimento incessante que ocorre no mundo visível e invisível, expresso pela obra artística, literária ou figurada. Herberto Helder, tendo tal conhecimento, é capaz de dizer que a metamorfose é "uma lei que abrange tanto o mundo das coisas como o da imaginação". No que tange à presença de "traços barrocos" na poesia herbertiana, vemos que a equivalência entre pintura e poesia data 
desde a Antiguidade, sendo o barroco do século XVII e XVIII, o ponto alto desta relaçáo. É o que veremos quando da leitura dos estudos de Ana Hatherly sobre os textos-visuais portugueses dos séculos XVII e XVIII. ${ }^{55}$

Com Helmut Hatzfeld, ${ }^{56}$ vemos que é possível tecer um paralelo entre as artes barrocas, sendo que no caso da análise do autor o paralelo estabelecido é, justamente, entre pintura e poesia, uma vez que o ponto em comum entre elas, segundo ele, é o fato de ambas serem as representaçôes dos anseios e angústias de uma determinada época. A análise de Hatzfeld demonstra, tal como é proposto por Wölfflin, que as formas artísticas do Barroco são comuns a todas as artes do período: arquitetura, pintura, música, poesia, etc. Sendo assim, o barroco na poética herbertiana é a encenação da equivalência entre artes até então consideradas distintas. Equivalência essa permeada pelo jogo entre os sentidos, pois não é apenas a visão e audição que são solicitadas, mas todos os demais sentidos contribuem para a configuração da imagem presente no poema.

Os "traços barrocos" em Herberto Helder são marcados pelos pressupostos que definiam a qualidade de uma obra no século XVII. Naquela época, uma obra para ser considerada como tal deveria apresentar o máximo de engenho e agudeza possíveis, sendo que ambos os procedimentos eram processados pela emulação, que é um gesto de prática, apropriação e representação, que determinava o grau de agudeza do criador da representação. $\mathrm{Na}$ verdade, mais do que isso, a agudeza e engenho eram os instrumentos de representação do irrepresentável, que, no caso, do século XVII, seria o divino, e que na modernidade é o real, o mundo. Sendo que tal façanha, no período barroco, só era conseguida com a junção de quatro elementos característicos de todas as representaçôes: Imaginação, Razão, Intelecto e Metáfora. Isto é, era preciso ter conhecimento, destreza e saber para criar e quanto mais isso fosse perceptível no processo operatório melhor seria a representação. Além do mais, nas obras literárias daquele período era imprescindível mostrar a operação do ato em si, não apenas os seus resultados. Era comum nas representaçóes o criador explicar o processo de composição de sua representação, pois “o corpo das imagens que é tornado visível pelo intelecto em ato é também condição objetiva da visibilidade das operações do próprio intelecto em ato. Por ser iluminado pela luz invisibilíssima, realiza sua presença fugidia e universal." 57

A iluminação dos "corpos das imagens" ocorre em via de mão dupla: a luz é jogada sobre o corpo, objeto, entretanto, ele próprio irradia luz que ilumina o que está a sua volta. Literalmente, é uma relação especular o que vemos nas representaçôes, obras barrocas do século XVII. É justamente essa iluminação que revela a relação entre os seres, objetos e os conceitos díspares e de uso comum. A relação entre os seres, objetos e conceitos no ato inte-
55 Cf. HATHERLY, Ana. A casa das musas: uma releitura critica da tradição, 1995.

56 Cf. HATZFELD, Helmut. Estudos sobre o Barroco, 2002.

57 HANSEN, João Adolfo. "Barroco, neobarroco e outras ruínas", 2012, p. 190. 
58 LOPES, Graça Videira. "A poesia ao espelho". Abril. Revista do Núcleo de Estudos de Literatura Portuguesa e Africana da UFF, v.7, n.15, p. 210.

59 Ibidem, p. 210.

60 Ibidem, p. 212. lectual da representação será compreendida por Hansen como sendo uma "teatralização do conceito", pois o objetivo da representação não era expressar ou criar um conceito, ao contrário, era o pôr em cena, demonstrando de que maneira ele estava presente na realidade do tempo, bem como era explicado pelos grandes mestres. Será a produção de semelhanças e não a reprodução que irá aproximar objetos, conceitos, seres e ideias, totalmente opostos, dentro da representação.

Para finalizar, vemos que os barroquismos - retomando as consideraçôes de Krysinski debatidas no início deste trabalho - presentes na obra poética de Herberto Helder não seriam possíveis sem o estabelecimento da relação poesia e crítica, pois, segundo Graça Videira Lopes é de conhecimento comum que "falar de poesia, hoje, não é, pois tarefa exclusiva da crítica, entendida como espaço autônomo e distinto. Pelo contrário: crítica e poesia mantêm neste início do século XXI relaçôes tão estreitas como ambíguas." 58 A autora irá considerar que tal relação é por demais extensa o que acaba por dificultar a proposta de uma análise que consiga condensar as diversas formas de relaçóes crítico-poéticas existentes. Para ela, esta dificuldade deve-se a falta de movimentos estéticos coletivos, uma vez que, hoje em dia, "cada poeta tende a ser um mundo [ao] desenvolver uma poética própria, pelo que seria impossível analisar as referências metapoéticas de cada um em particular." ${ }^{59}$ Nesse sentido, para a autora - e também para nós -, a obra poética de Herberto Helder é um paradigma "da fluidez ou da porosidade de fronteiras entre Poesia e Crítica", ${ }^{60}$ o que demonstra que seu projeto poético foi, na verdade, um ver, fazer e falar da poesia.

\section{Referências}

ALVES, Ida. "Paisagem e poesia: uma certa maneira de ver e escrever". Anais do XI Congresso Internacional da ABRALIC Tessituras, Interaçöes, Convergências. 2008. Disponível em http://www.abralic.org.br/eventos/cong2008/AnaisOnline/simposios/pdf/039/IDA_ALVES.pdf Acesso em 19 de março de 2017.

"Em torno da paisagem: literatura e geografia em diálogo interdisciplinar". Revista da Anpoll. n. 35, Florianópolis, p. 181-202, jul./dez. 2013.

"Paisagem, aceleração e poesia por uma geografia das emoçóes". Revista de Letras. n.34, v.1, p. 27-38, jan./jun. 2015.

CAMÕES, Luís de. "Mudam-se os tempos, mudam-se as vontades". In: Versos e alguma prosa de Luis de Camóes. Ediçẫo da Fundação Calouste Gulbenkian. Lisboa: Moraes Editores, 1977. p. 45. 
em revista. v.6, n.1, p. 86-92, julho 2008.

DU BOS, Jean-Baptiste. "Reflexôes críticas sobre a poesia e a pintura". In: LICHTENSTEIN, Jaqueline (Org.). A pintura: textos essenciais (Vol. 7: Paralelo das artes). São Paulo: Editora 34, 2005. P. 60-73.

DELACROIX, Eugène. "Diário (1822, 1853, 1854)". In: LICHTENSTEIN, Jaqueline (Org.). A pintura: textos essenciais (Vol. 7: Paralelo das artes). São Paulo: Editora 34, 2005. P. 93-101.

HANSEN, João Adolfo. "Barroco, neobarroco e outras ruínas". In: IVAN, Francisco; LIMA, Samuel. (Org.). Colóquio Barroco III. Natal, RN: Editora da UFRN, 2012, p. 131-209.

HATZFELD, Helmut. Estudos sobre o Barroco. Tradução Célia Berrettini. 2a edição. São Paulo: Editora Perspectiva, 2002.

HELDER, Herberto. Os passos em volta. Portugal: Assírio \& Alvim, 2013.

"A morte sem mestre". In: Poemas Completos. Porto: Porto Editora, 2014. p. 713-752.

"Servidôes". In: Poemas Completos. Porto: Porto Editora, 2014. p. 621-709.

JÚDICE, Nuno. "As fronteiras do poético na poesia de Herberto Helder". Diacrítica: Revista do Centro de Estudos Humanísticos. n.23/3, 2009a.

. "Um conceito de poética". Abril. Revista do Núcleo de Estudos de Literatura Portuguesa e Africana da UFF. v.2, n.3, p. 154-159, 2009 b.

KRYSINSKI, Wladimir. "Os barroquismos da modernidade". In: NITRINI, Sandra. et al. (Org.). Literaturas, Artes, Saberes. São Paulo: Aderaldo e Rothschild, ABRALIC, 2008, p. 164-185.

LINS, Vera. "Fragmentos sobre poesia e pintura". Alea: Estudos Neolatinos. v.3, n.2, p. 23-29, julho/dezembro de 2001.

LOPES, Graça Videira. "A poesia ao espelho". Abril. Revista do Núcleo de Estudos de Literatura Portuguesa e Africana da UFF. v.7, n.15, p. 209-218, 2015.

MARTELO, Rosa Maria. "De imagem em imagem”. Abril. Revista do Núcleo de Estudos de Literatura Portuguesa e Africana da UFF. v.5, n.9, p. 15-26, 2012.

PITERI, Sônia Helena de Oliveira Raymundo. "Palavras em desdobramento na poesia de Herberto Helder”. Forma breve. n.7, 2010, p. 395-401. 
SOARES, Maria Leonor Barbosa. "Formas e sentidos do barroco na arte contemporânea”. Actas do II Congresso Internacional do Barroco. p. 553-562, 2003. Disponível em: http://ler.letras.up.pt/uploads/ficheiros/7440.pdf. Acesso em 25 de fevereiro de 2017.

WÖLFFLIN, Heinrich. Renascença e Barroco. Tradução Mary Amazonas Leite e Antonio Steffen. São Paulo: Editora Perspectiva, 2012.

Submissão: 14/09/2017

Aceite: $13 / 10 / 2017$

https://doi.org/10.5007/2176-8552.2017n24p85

100 - outra travessia 24 - Programa de Pós-Gradução em Literatura 